\title{
Canada From Afar: Canadian Naval Persons in the Daily Telegraph Obituaries
}

\section{Peter Hore}

\begin{abstract}
Souvent, "ce qu'a fait papa à la guerre », ce qu'il a dit à ses enfants, ce dont ils se souviennent qu'il a dit et ce qui relève de l'histoire officielle représentent une demi-douzaine de contes différents. L'auteur dit aimer le sauvetage des fins détails du drap touffu de l'histoire navale. En tant que nécrologue navale depuis 2002, sa tâche a été d'établir la base absolue de la vérité sur la vie et les réalisations d'un individu; d'en faire une description sans hésitation, déviation ou répétition, et ceci à un lectorat généraliste; et de le faire avec un minimum d'adjectifs et d'hyperbole. Ce document met en évidence l'intérêt que les lecteurs d'un journal londonien a démontré pour la vie des officiers de la marine canadienne et la façon dont leurs réalisations ont été rapportées.
\end{abstract}

The Daily Telegraph is perhaps the most Empire-minded of the British national newspapers, and so it is quite natural that Canadian naval officers, who as a cohort have played such prominent roles in the wars of the twentieth century, should appear in significant numbers in its pages. ${ }^{1}$

One of the oldest officers to appear in the obituary pages was Captain Ken Cummins who died on 11 December 2006 aged 106 and was one of the last half dozen men to have served in both world wars of the century. ${ }^{2}$ Cummins' Canadian connection was that in 1918 he was a junior officer in the P\&O's liner Morea which had been turned into an armed merchant cruiser. On the night of 27 June 1918, the Canadian hospital ship Llandovery Castle was torpedoed by the German submarine U-86 (Kapitänleutnant Patzig) a hundred miles south west of Fastnet rock. Patzig then rammed and sank all the lifeboats except one, which managed to escape in the dark. Two hundred and thirty-four died that night including fourteen nurses.

In his poignant memoirs, Cummins recounted searching the area and seeing the corpses of nurses being driven across the mirror of the sea by their billowing aprons and skirts which had dried in the hot sun to form sails. The risk of being torpedoed barred

1 Most of the archive of Daily Telegraph obituaries is now online at http://www.telegraph.co.uk. In addition the author has a collection of unpublished obituaries.

2 Ken Cummins, published in the Daily Telegraph, 12 December 2006.

The Northern Mariner/Le marin du nord XXIV, Nos. 3 \& 4 (Jul. \& Oct. 2014), 357-363 Canadian Military History 23, Nos. 3 \& 4 (Summer \& Autumn 2014), 357-363 
any recovery of bodies. The Canadian reaction was typified by Brigadier George Tuxford, a former homesteader from Moose Jaw, Saskatchewan: amongst those murdered were two Moose Jaw nurses, Marjory Fraser and Minnie Gallagher. ${ }^{3}$ Tuxford gave orders to his brigade that the battle cry on 8 August 1918 should be "Llandovery Castle!" and that these should be the last words to ring in the ears of the Hun as the bayonet was driven home. ${ }^{4}$ It is likely no longer politically correct to do such a thing.

Another 106-year old veteran was Henry John Lawrence Botterell, who was known as 'Nap' because his friends thought he looked like Napoleon. ${ }^{5}$ Born in Ottawa on 7 November 1896, Botterell was the last surviving pilot of the First World War, and links us to a man who must surely be honoured on the centenary of the Royal Canadian Navy: Charles Kingsmill, the first Director of the Canadian Naval Service. Botterell's older brother had been killed in action in France serving in the Toronto $48^{\text {th }}$ Highlanders, when Kingsmill received from London the Admiralty's call to help it find suitable young men to train as pilots in the Royal Naval Air Service. As it happened, Botterell's sister, Edith, worked in Kingsmill's office and she was able to advise Nap to travel to England to train, initially as a civilian pilot, before being commissioned into the RNAS on 16 May 1917.

The highlights of Botterell's flying career are soon told: he joined No 8 Naval Squadron which was reinforcing the Royal Flying Corps on the Western Front, and where his leader was the ace James White from Ontario. Botterell flew the Grahame-White, the Maurice Farman, the Sopwith Snipe, the RE8 and the SE5, but on only his second operational flight in a Sopwith Pup, it stalled, spun and hit the ground, breaking his thigh, knocking out some teeth and gashing his head. Botterell spent six months in hospital, then was invalided out of the service and was due to be repatriated to Canada when he met some of his Naval 8 chums who had flown from France to London for a run ashore in London. They arranged, instead, for him to re-join Naval 8.

Botterell was involved in patrols and artillery spotting, operations that were so intense in June, July and August 1918, that he flew 91 sorties in 60 days. On several occasions he flew three combat missions a day. In all, he notched up 251 combat hours in his Camel, taking part in seven dogfights, from which he returned every time with bullet holes or flak damage to his machine. However, he made his rite of passage when he shot down a balloon on 29 August 1918. As the balloon began to crumple at about 1,000 feet, the German observer leapt from the basket with his parachute and Botterell banked to avoid him: he could see the fear in his face, but in the best traditions of knighthood he gave the defenceless man a wave and flew home.

Incidentally, there were forty-five Canadian aces in the Royal Naval Air Service who shared 575 kills, the highest number claimed being 60 by Raymond Collishaw, born

3 Born in Wales in February 1870, George Tuxford emigrated to Moose Jaw with his wife in the 1890s. He commanded the 3rd Canadian Infantry Brigade at the Second Battle of Arras (August-September 1918), and the Battle of the Hindenburg line (September-October 1918).

4 James McWilliams and R. James Steel, Amiens - Dawn of Victory (Dundurn, 2001), 31.

$5 \quad$ Henry Botterell, published in the Daily Telegraph, 7 January 2003. 
in British Columbia in 1893, who became Air Vice-Marshal Collishaw, CB, DSO \& Bar, OBE, DSC, DFC, RAF, but who started life as a 15 -year old cabin boy in the Canadian Fisheries Protection Services.

The Royal Canadian Navy suffered a decline between the wars, so that when Alexander Beaufort Fraser-Harris, born in Nova Scotia on 16 November 1916, where his father was professor of physiology at Dalhousie University, wanted to go to sea, he was obliged to cross the Atlantic and join the Royal Naval College, Dartmouth under a Commonwealth scholarship scheme. Fraser-Harris became Cadet Captain and played for the rugby first $\mathrm{XV}$, but while under training in the battlecruiser Repulse, her captain, Tom Phillips, discouraged Fraser-Harris' ambition to fly by telling him that gunners and navigators had better career prospects. (Phillips later commanded Force $\mathrm{Z}$ when it was overwhelmed by Japanese aircraft in 1941.) Meanwhile at dawn on 10 April 1940, during the German invasion of Norway, Fraser-Harris was Blue Three of the first wave of Blackburn Skua dive-bombers from 800 and 803 Naval Air Squadron which struck at the German cruiser Königsberg. Flying at extreme range from Hatston in the Orkneys and in poor weather, Fraser-Harris dived from 8,000 feet through a thin layer of cloud, at about 60 degrees angle and with the sun behind him. His 500-lb semi-amour piercing bomb was seen to hit the cruiser's bows making a large flaming hole. Surprise was complete, and the Fleet Air Arm had achieved the first sinking of a major warship in wartime by aerial bombing. Fraser-Harris was mentioned in despatches and awarded the DSC for his daring and resource. ${ }^{6}$

And in November 1941 Fraser-Harris found himself airborne in a Fairey Fulmar when his carrier, Ark Royal, was torpedoed and sank. Next Fraser-Harris commanded the reformed 807 NAS which, during Operation Harpoon (the Malta re-supply convoy of June 1942), shot down four Italian aircraft and he was awarded a bar to his DSC for his bravery and resolution. During Operation Torch (the Allied landings in North Africa), and now flying Seafires, Fraser-Harris's squadron downed three more aircraft and destroyed another twenty on the ground.

After a busy war, Fraser-Harris transferred to the Royal Canadian Navy - where he wanted to be at the start - and by 1948 aged 32 he was the youngest captain in any Commonwealth navy. In the Korean War, Fraser-Harris commanded HMCS Nootka, and the Americans made him a legionnaire of the Legion Merit with combat distinction "for exceptionally meritorious service in the performance of outstanding services... expert seamanship, sound judgement and devotion to the highest traditions of the naval service." Just as appreciative but more laconic, the British awarded him a mention in despatches.

Incidentally, also during the Norway campaign where Fraser-Harris first made his name, another Canadian, Alec Dennis, made the first capture of Enigma. Dennis was a junior officer in the destroyer Griffin off Norway on 26 April 1940 when:

A lookout sighted a trawler marked with a big painted Dutch Flag steaming northwards. As we approached her it became obvious that a boat abaft her funnel was nothing more than a canvas mock-up. There wasn't time to be

6 Alexander Beaufort Fraser-Harris, published in the Daily Telegraph, 8 November 2003. 
more than normally frightened and in only a minute or two we were alongside, heaving up and down in the swell. I leaped on board, to be confronted by a slightly dazed looking individual who at once announced the words "German Ship". The canvas mock-up covered a gun and right away I could see her two torpedo tubes barely covered by fishing nets. The rest of my party scrambled aboard and we quickly got the German crew on deck. We brandished our loaded .45 pistols just like in the movies and they didn't resist but threw overboard all their confidential books, ciphers and charts. The books did not sink at once and were recovered very gallantly by Florrie Ford who dived from Griffin's quarterdeck into the rough sea. He was not far from drowning but was successfully hauled back with his bag of books. ${ }^{7}$

More than 60 years came to pass before, in a series of telephone call interviews between London and Vancouver with Hugh Sebag-Montifiore, "usually at two in the morning," Dennis realized the importance of his capture.

Another Canadian who made his mark was Tommy Ladner, who pre-war proposed in his university debating society in British Columbia "that in the event of Britain going to war, Canada should withdraw from the Empire," but then, on a sailing holiday off Vancouver in September 1939, he and two friends - Cornelius 'Corny' Burke and Douglas 'Wimpy' Maitland - heard the BBC news, and all volunteered for the Royal Canadian Navy where they became known as 'the three musketeers'.

Ladner's war did not start too well: on 2 December 1940 his first ship, the armed merchant cruiser Forfar, was hit by a torpedo from Otto Kretschmer's submarine U-99 west of Ireland. As Ladner struggled to launch a lifeboat, it was destroyed by an explosion and he fell into the icy water wearing a lifebelt over his great coat. Covered in oil, he climbed onto a Carley float and paddled to a lifeboat where he helped to haul in others. He was one of only 21 men from Forfar who survived a stormy day and night in the frigid North Atlantic until rescued by the British merchant ship Dursley; 171 others died.

Next Ladner and his friends volunteered for coastal forces: the $56^{\text {th }}$ MGB Flotilla, sometimes known as 'the cowboy flotilla' because all the boats were commanded Canadians; they entered the war in the Mediterranean. By war's end, Maitland had earned a DSC and bar and the Croix de Guerre and had been twice mentioned in despatches; Burke had a DSC and two bars and had been mentioned in despatches once; and Ladner was awarded the Distinguished Service Cross with bar and was mentioned in despatches four times. ${ }^{8}$ Incidentally, as a youth Ladner had ridden the ferry across Burrard Inlet to West Vancouver and hiked up the mountain to ski at Hollyburn; later, he became one of the original investors who turned an isolated valley lacking all facilities into the skiing resort of Whistler, and he also lobbied for Vancouver to be awarded the 2010 Winter Olympics.

Someone else who was torpedoed was Yogi Jenson from Calgary; he survived a 
sinking and enjoyed a run of luck (he was appointed away from first the destroyer Matabele and then the battlecruiser Hood before they each were sunk) to become one of Canada's most famous marine artists and historical illustrators. Jenson was the 21-year old gunnery officer of HMCS Ottawa when on 14 September 1942, 500 miles off Newfoundland, Kapitänleutnant Heinz Walkerling commanding the German U-boat U-91 fired two torpedoes and observed a hit. As the mortally wounded Ottawa stopped, Jenson recalled "grotesquely twisted limbs... like a scene from hell" as he tried to restore order between decks. Ten minutes later Walkerling fired a second salvo of torpedoes which hit amidships, causing Ottawa to blow up. ${ }^{9}$

In the dark, Jenson was flung overboard: he was surprised to find that the water was cold but not freezing and he remembered that they were in the Gulf Stream. As he looked round he saw, seemingly in slow motion, "Ottawa's stern tipping out of the water as the bows sank. Soon the rudder and propellers were right out of the water, and the 4.7inch gun slipped out of its mounting and plunged downward. The stern now vanished beneath the waves. It was like a dream." Thick furnace fuel oil spread over the sea covering Jenson's face, head and hands, and filling his nostrils and mouth. In the heaving sea and inky darkness, Jenson repeatedly recited the Lord's Prayer and clung on to life for five hours. The board of inquiry into Ottawa's loss commended Jenson, "who for a young officer, displayed considerable initiative and powers of command."

Jenson's next ship was Algonquin, which he described as "the fairest of my loves" and was commanded by Lieutenant-Commander Desmond ('Debby') Piers. Debby Piers could claim descent from the founding fathers of Halifax in the eighteenth century. He joined the navy from the Royal Military College, Kingston in 1932, and by November 1942 he was the youngest-ever destroyer captain in the RCN, in command of 'Rusty Guts', HMCS Restigouche. He was the escort commander for Convoy SC 107 made up of 42 ships outward bound from Canada. Only Restigouche had high-frequency direction-finding (HF/DF) equipment, which Piers had scrounged earlier off an American ship in Londonderry. Four other corvettes in the escort either had new captains or were fitted with unreliable radar and short-range ASDIC. When the convoy was attacked west of Cape Race by an estimated 17 U-boats, Piers used his HF/DF to sweep aggressively around the convoy driving off shadowers early in the battle, but his escort was overwhelmed. Eight ships were sunk on the first night, and seven more in the next week. Piers had fought fiercely but Royal Navy criticism was harsh, senior officers believing that the Royal Canadian Navy had expanded too rapidly, taken on too many tasks, and was poorly trained and led, and that Piers was young and inexperienced. Canadian officers quipped that certainly Piers was young but he had three years' experience in the North Atlantic. ${ }^{10}$

When Piers left Restigouche in June 1943, he was acknowledged for the fine seaman he was, and as a brilliant tactician. He also took a keen interest in the welfare of his sailors, and in a hard-hitting report he recommended better equipment, more home leave and regular mail, longer work-up periods, fewer short-term appointments and better

9 Yogi Jenson, published in the Daily Telegraph, 23 May 2005.

10 Debby Piers, published in the Daily Telegraph, 15 November 2005. 
individual training. The ensuing reforms much improved the fighting performance of the rapidly expanding Canadian navy. The citation for his DSC read: "This officer has served continuously in His Majesty's Canadian destroyers since the commencement of hostilities. As Senior Officer of Convoy Escort Groups in the North Atlantic, he has, by his vigorous leadership and aggressive attack, been an inspiration to those under his command."

Canadians took active parts in every campaign of the Second World War. An adoptive Canadian, Hank Rotherham started the hunt for the Bismarck in May 1941. The weather in the Orkneys had prevented flying for several days when news came through that the German battleship Bismarck and the cruiser Prinz Eugen had sailed from the Baltic. Hank immediately volunteered with a scratch crew for a reconnaissance mission of the Norwegian fjords in a Maryland bomber, and in low cloud and strong winds navigated the Maryland to Marsten on the Norwegian coast, sometimes flying as low as 50 feet both to avoid German radar and to be able to estimate wind speed accurately. $\mathrm{He}$ made a perfect landfall and then, though under heavy ack-ack fire, searched the fjords so thoroughly that he was able to signal confidently on an emergency frequency, "Battleship and Cruiser have left": his signal set in motion the hunt for the Bismarck. Hank was awarded an immediate DSO. Post-war, Hank asserted the independence of the RCN Air Branch over the RCAF, and when he thought a poorer-performing American aircraft might replace an order for Sea Furies from Britain he intervened to hasten the delivery of aircraft from Hawker. In retirement he became an estate agent around Knowlton, Quebec, before settling on Saltspring Island, British Columbia.

Another adoptive Canadian was Mac Samples, the observer in Sub-Lieutenant Pat Kingsmill's Swordfish, one of six aircraft of 825 Naval Air Squadron, stationed at Manston in Kent, which flew in a forlorn hope against the heavily-escorted German battleships Scharnhorst and Gneisenau and the battlecruiser Prinz Eugen when they made their infamous Channel Dash from western France to the North Sea. As they took off, the station commander, Wing Commander Tom Gleave, stood in the snow to salute the eighteen heroic naval airmen in their six Swordfish: all were shot down and Mac was one of only five survivors.

As Kingsmill (no relation to Admiral Sir Charles), third to attack the German fleet, levelled up for his torpedo drop, Mac saw that the fabric of the aircraft's wings was torn and full of holes by enemy flak, but amazingly the Swordfish flew on until a cannon shell hit the fuselage immediately between Kingsmill and Samples, wounding both. ${ }^{11}$ The air gunner, Don Bunce, saw Samples covered in blood as he continued to shout directions to the pilot and to Bunce at his Vickers machinegun. Mac could see the German gunners in their sleek, black anti-flash overalls, when he felt a sudden burning sensation in his leg, and looking down at his flying boots was astonished to see that in one there was a neat pattern of bullet holes through which the blood oozed into the sea through the torn fabric of the bottom of the fuselage. Despite his wounds, Mac climbed up to the pilot and shouted directions into his ear. Mac was awarded the DSO for his

11 Pat Kingsmill, published in the Daily Telegraph, 6 February 2002. 
conspicuous gallantry. ${ }^{12}$

There are other Canadian heroes such as: Sub-Lieutenant Rod Dove, who earned the DSO during a daring attack on Italian shipping by riding a human torpedo into Palermo harbour, and who settled on the shores of Hay Bay, Lake Ontario; ${ }^{13}$ Mike Langman, who enjoyed three distinct flying careers, served in the wartime RN and the post-war RCN, and was recognized for his bravery over the Western Desert and the Mediterranean; ${ }^{14}$ Dicky Kendall who placed a two-ton mine under the German battleship Tirpitz; ${ }^{15}$ and Graham Bridgman, who started life as a horse breaker with an ambition to get out of Saskatchewan, and who rose to be senior naval engineer of the Royal Canadian Navy. ${ }^{16}$

And there were talented admirals, like: Bob Timbrell, an inspirational leader, the first Canadian of the war to be awarded a DSC, for captaining a boat back and forth to Dunkirk, rescuing some 900 soldiers, ${ }^{17}$ Bob Falls, skilled seaman and aviator, who was the first naval officer to be Chief of the Defence Staff; ${ }^{18}$ and Bill Landymore, who led a campaign to preserve the distinct role, identity and skills of the Royal Canadian Navy. ${ }^{19}$

However, war at sea is about preservation from the dangers of the sea as much as from the violence of the enemy. So finally I should like to mention an unknown Canadian. In January 1943, HMS Roxborough was caught in some of the worst Atlantic weather of the war: a monster wave washed away her bridge superstructure and eleven men, including her captain, first lieutenant, and navigator, leaving a 21-year old Canadian sub-lieutenant - whose name is unknown - this young man took command of his ship from the emergency conning position and using hand steering brought her wrecked hull into Halifax. $^{20}$ I hope someone can tell me his name and I'd like to know that he was properly rewarded.

These Canadians, from all walks of life - horse-breaker, banker, lawyer, farmer and forester - were not exceptions to any rule. Rather, they epitomized Canada, Canadians and their navy. And whether they joined the navy for the duration of their respective wars or they were career officers or they were adoptive Canadians, they loved their country, and in crisis - as they have shown for a hundred years - they rose to meet the occasion, and displayed great resource and courage of the highest order.

12 Mac Samples, published in the Daily Telegraph, 17 August 2009.

13 Rod Dove, published in the Daily Telegraph, 20 December 2005.

14 Mike Langman, published in the Daily Telegraph, 19 January 2010.

15 Dicky Kendall, published in the Daily Telegraph, 8 April 2006.

16 Graham Bridgman, published in the Daily Telegraph, 1 March 2005.

17 Bob Timbrell, published in the Daily Telegraph, 27 April 2006.

18 Bob Falls, published in the Daily Telegraph, 18 November 2009.

19 William Landymore, published in the Daily Telegraph, 15 February 2010.

20 See James Watt, published in the Daily Telegraph, 21 January 2010. 